Published in final edited form as:

Semin Reprod Med. 2010 January ; 28(1): 81-90. doi:10.1055/s-0029-1242998.

\title{
Role of Progesterone in Endometrial Cancer
}

\author{
J. Julie Kim, Ph.D. ${ }^{1}$ and Eloise Chapman-Davis, M.D. ${ }^{1,2}$ \\ ${ }^{1}$ Department Obstetrics and Gynecology, Robert H. Lurie Comprehensive Cancer Center, \\ Northwestern University, Chicago, Illinois \\ ${ }^{2}$ Division of Gynecologic Oncology, Northwestern University, Chicago, Illinois
}

\begin{abstract}
Progesterone is a key hormone in the endometrium that opposes estrogen-driven growth. Insufficient progesterone will result in unopposed estrogen action that could lead to the development of endometrial hyperplasia and adenocarcinoma. Although these endometrial neoplasias can regress in response to progestin treatment, this does not occur in all instances. To understand this resistance to progesterone and to improve on existing hormonal therapies, it is imperative that the molecular mechanisms of progesterone action through its receptor be deciphered in endometrial cancer. This review highlights what is known thus far regarding the efficacy of progestin therapy in the clinic and the role of progesterone in endometrial cancer cell behavior and gene regulation.
\end{abstract}

\section{Keywords}

Progesterone receptor; endometrial cancer; uterus; progesterone

\begin{abstract}
Endometrial hyperplasia or adenocarcinoma arise from the endometrial glands, and its incidence is highly associated with prolonged unopposed estrogen action. These tumors can respond to progestins and regress. Thus hormonal therapy has been used as an alternative treatment for a specific subset of patients where preservation of fertility is desired or if comorbidities exclude them from surgical intervention. Progestin therapy is also given when endometrial cancer recurs, although response rates are relatively low. Studies suggest that the efficacy of progestin treatment diminishes as the neoplasia becomes more aggressive. For example, the response rate to progestins in cases of endometrial hyperplasia is higher compared with endometrial adenocarcinoma, whereas response to progestins in cancer recurrence is the worst. The mechanisms for resistance to progesterone are unclear. To better understand the role of progesterone in endometrial neoplasia, we review the studies that investigate progesterone action in the normal cycling endometrium as well as in endometrial neoplasia and summarize some of the key clinical studies that demonstrate efficacy of progestin therapy.
\end{abstract}

\footnotetext{
Address for correspondence and reprint requests: J. Julie Kim, Ph.D., Assistant Professor, Division of Reproductive Biology Research, Department Obstetrics and Gynecology, Robert H. Lurie Comprehensive Cancer Center, Northwestern University, 303 E. Superior Street, 4-117, Chicago, IL 60611 (j-kim4@northwestern.edu).
} 


\section{ROLE OF PROGESTERONE IN THE NORMAL CYCLING ENDOMETRIUM}

The endometrium is the tissue that lines the uterine cavity and consists of a layer of columnar luminal epithelium supported by cellular stroma with tubular glands (Fig. 1). The luminal and glandular cells of the endometrium originate from the paramesonephric duct epithelium during development; the stroma originates from the mesenchyme surrounding the urogenital ridge. ${ }^{1}$ From the onset of puberty to menopause, the endometrium undergoes extensive remodeling in response to the ovarian steroid hormones estrogen and progesterone during each menstrual cycle in preparation for implanting an embryo. Estrogen promotes proliferation and growth of the endometrial lining while progesterone antagonizes estrogendriven growth and promotes differentiation. ${ }^{2}$ Specifically, when progesterone levels are high during the luteal phase of the menstrual cycle, the glandular epithelium transforms from relatively inactive cells full of free ribosomes to very active polarized cells, containing giant mitochondrial profiles, intracellular deposits of glycogen/glycoprotein-rich material, and a complex intranuclear channel system. ${ }^{3}$ Morphologically, the glands become tortuous and have large lumens due to increased secretory activity. In parallel, the underlying stroma becomes very edematous as a result of increased capillary permeability, and the cells begin to appear large and polyhedral. This transformation process, termed decidualization, begins in the stroma around the spiral arteries when progesterone levels are high during the midluteal phase and spreads to the upper two thirds of the endometrium. ${ }^{4}$ If embryo implantation occurs, the reaction is intensified and becomes the decidua of pregnancy. The decidualized cell biochemically expresses new proteins such as insulinlike growth factorbinding protein- 1 and prolactin. ${ }^{5}$ If there is no pregnancy, levels of estrogen and progesterone decline due to the regression of the corpus luteum, causing the upper two thirds of the endometrium to be shed.

Progesterone is central in the remodeling that occurs in the endometrium and acts on both the epithelial and stromal compartments. Studies in mice with selective ablation of progesterone receptor (PR) isoforms revealed that PR-A modulates the antiproliferative effects of progesterone in the uterus and PR-B, in the absence of PR-A, induces cell growth. ${ }^{6}$ Whether these differences on uterine cell proliferation occur in the human endometrium remain to be clearly demonstrated. PR-A and PR-B are transcribed from the same gene by two distinct promoters, with PR-A lacking 164 amino acids at the amino terminus, ${ }^{7-9}$ and they have been proven to have distinct transcriptional activities. ${ }^{10-17}$ PR-A and PR-B are expressed in the epithelial and stromal cells of the endometrium and depend on hormonal status. In the glandular epithelium, PR expression is stimulated by estrogen during the proliferative phase but is downregulated by its own ligand in the secretory phase. Prior to ovulation, PR-A and PR-B levels are approximately equivalent in glandular epithelium and thereafter decrease rapidly during the secretory phase until they are almost undetectable at the end of the menstrual cycle. ${ }^{18}$ In constrast, PR expression in the stroma is consistent throughout the cycle, and some studies show that PR-A is the predominant isoform in the stroma. ${ }^{19-21}$ 


\section{ENDOMETRIAL CANCER}

Strong evidence indicates that in the cycling endometrium, progesterone negatively regulates estrogen-driven growth. However, when there is either insufficient progesterone action or an excess in estrogen, this can result in endometrial pathologies such as endometrial hyperplasia or endometrial adenocarcinoma (Fig. 1). Endometrial cancer is the most common gynecologic malignancy diagnosed in the United States. The American Cancer Society estimated 40,100 new cases of endometrial cancer to be diagnosed with $\sim 7470$ deaths in $2008 .^{22}$ Approximately $80 \%$ of all endometrial carcinomas are the endometrioid type, which arise from endometrial glands. These tumors, also known as type 1 endometrial carcinomas, are associated with chronic exposure to estrogen and insufficient opposing progesterone. The reasons for this chronic unopposed estrogen exposure are multifactorial because high levels of estradiol and insufficient progesterone could arise from various conditions such as anovulation, polycystic ovarian syndrome, obesity, estrogen-only hormone replacement therapy, and prolonged tamoxifen use. ${ }^{23-25}$ Although more than half of these cancers are diagnosed in postmenopausal women from the ages of 55 to 74 uears, $\sim 5 \%$ of women with this disease are diagnosed $<40$ years of age, and 20 to $25 \%$ are diagnosed before menopause. ${ }^{26}$ This paradigm shift to younger ages will continue due to an increase in risk factors such as marked obesity, diabetes mellitus, and hypertension.

\section{CLINICAL USES OF PROGESTINS IN ENDOMETRIAL NEOPLASIA}

\section{Standard Treatment of Endometrial Neoplasia}

The treatment for patients diagnosed with endometrial neoplasia is surgery, including total abdominal hysterectomy and bilateral oophorectomy with further staging depending on risk factors. This is true for both endometrial adenocarinoma and atypical endometrial hyperplasia. The main purpose for treating simple or complex endometrial hyperplasia without atypia is for symptom control, with only a 1 to $3 \%$ risk of progression to actual cancer. This is not the case with atypical endometrial hyperplasia, which if left untreated, will progress to carcinoma in $\sim 30 \%$ of cases. Furthermore lies the possibility of missing underlying concurrent carcinoma, which is documented to be as high as $42 \%$ within uterine specimens. ${ }^{26,27}$ Hysterectomy may not be an acceptable option for young women diagnosed with complex atypical hyperplasia and/or endometrial cancer prior to completing childbearing. This may also be true for patients with multiple comorbidities who are poor surgical candidates. In this subset of patients with either complex atypical hyperplasia of endometrium or clinical stage 1A low-grade uterine tumors, progesterone therapy may be an acceptable alternative for primary management.

\section{Progestin Therapy in Endometrial Hyperplasia}

Consistently, studies have shown that progestins are effective for treatment of endometrial hyperplasia. Progestin therapy has an impact on the endometrial cells as early as 10 weeks after initiation of treatment, but most recognize the need for a minimum of 3 months of progestin therapy before assessing for a response. ${ }^{28,29}$ Reversal of endometrial hyperplasia by progestins is thought to occur through activation of PRs, resulting in stromal decidualization and subsequent thinning of the endometrial lining. The doses and types of 
progestins for treating endometrial hyperplasia vary depending on presence of absence of atypia. Studies have shown regression of hyperplasia without atypia to normal endometrium in 80 to $90 \%$ of patients when treated with either medroxyprogesterone acetate (MPA), 10 $\mathrm{mg}$ daily for 12 to 14 days each month, or micronized progesterone in vaginal cream, when treated for 3 to 6 months. ${ }^{30-33}$ In a larger prospective study from the United Kingdom ( $n=$ 105), patients with endometrial hyperplasia were treated with a levonorgestrel intrauterine device (LNG-IUD). A reported 90\% (94 of 105) of patients had histologic regression after 2 years. Out of this group, only 67\% (6 of 9) of patients had "atypical" endometrial hyperplasia with most ( 88 of 96) having hyperplasia without atypia. ${ }^{34}$ Other successful treatments demonstrated for atypical hyperplasia include use of continuous oral megestrol acetate, starting $80 \mathrm{mg}$ daily up to $160 \mathrm{mg}$ per day, and oral MPA, $600 \mathrm{mg}$ daily. ${ }^{35,36} \mathrm{~A}$ reported $82 \%$ complete (14 of 17) and $18 \%$ partial response rate was found using the MPA regimen in a multicenter trial with only six recurrences found within 25- to 73-month follow-up. ${ }^{37}$ These studies demonstrate the relative efficacy of progestin therapy in endometrial hyperplasia with a significant number of cases resulting in complete response. As a precaution, follow-up biopsies are usually recommended.

\section{Progestin Therapy in Primary Endometrial Cancer}

Studies investigating the efficacy of progestin therapy in endometrial cancer have been limited to case series and pilot studies. Ramirez et a ${ }^{38}$ reviewed 27 articles for a total of 62 patients with stage $1 \mathrm{~A}$ endometrial cancer treated with progestins. Although $76 \%$ responded to treatment after 12 weeks, $24 \%$ who initially responded recurred. Seven of the patients with recurrence were retreated with progesterone, with five of seven having a complete response rate with no evidence of disease at 46-month follow-up. ${ }^{38}$ In a prospective, multicenter trial, 22 women with stage $1 \mathrm{~A}$ endometrial carcinoma in women $<40$ years of age were treated with oral MPA for 26 weeks followed by cyclic estrogen-progestin therapy for 6 months. Twelve (55\%) achieved a complete clinical response, seven with partial response and three had no change. ${ }^{37}$ In a review of articles published between January 1966 and January 2007 describing patients with endometrial cancer treated with hormonal therapy, 133 patients were identified who were treated for an average duration of 6 months and who demonstrated an average response time of 12 weeks. ${ }^{39}$ Of these 133 patients, $51 \%$ demonstrated a lasting complete response, $25 \%$ showed a temporary response, and $24 \%$ never responded to treatment. These studies highlight a 50 to $70 \%$ overall response rate for patients treated with high-dose progesterone therapy as primary therapy and also emphasize the need for close follow-up even in the responders because of the substantial rate of recurrence. ${ }^{35-38,40}$ Because of the high risk of recurrence, and ongoing risk factors for endometrial cancer (obesity, anovulation), most women eventually undergo total abdominal hysterectomy with bilateral oophorectomy.

Progestin-releasing IUDs used in patients with endometrial cancer with high surgical risk factors have yielded mixed results. Montz et $\mathrm{al}^{41}$ used the "progestasert" as the IUD in selected grade 1 endometrial cancer without any evidence of myometrial invasion, with a reported $(75 \%)$ complete response rate (six of eight patients) at 12 months. However, Dhar et $\mathrm{al}^{42}$ reported a case series of four patients with only $25 \%$ complete histologic regression at 6 months when using the LNG-IUD. In addition, others have reported failures of using 
LNG-IUD in cases of endometrial hyperplasia and cancer. ${ }^{43,44}$ Thus LNG-IUD may be beneficial, but there needs to be larger studies separating the atypical hyperplasia and cancer patients to determine its efficacy in these populations.

\section{Progestin Therapy in Recurrent Endometrial Cancer}

Progesterone agents have been extensively used in patients with advanced or recurrent endometrial cancer. Many of these patients have already undergone surgical procedures, chemotherapy, or both, with progressive disease or present with multiple comorbidities at an advanced age where hormonal therapy may be a therapeutic alternative. Early studies reported response rates as high as $56 \%$ with various treatment regimens (MPA, megace, hydroxyprogesterone caproate); ${ }^{28,45,46}$ however, with more stringent response criteria and larger multicenter cooperative studies, the objective response rates ranged from 15 to $20 \% .47,48$ In a major Gynecologic Oncology Group study, women with advanced or recurrent endometrial cancer were randomized to either low-dose (200 mg/day) or high dose $\left(1000 \mathrm{mg} /\right.$ day) oral MPA, with complete response rate of only $17 \%$ and $9 \%$, respectively. ${ }^{48}$ Progression-free survival was 3.2 versus 2.5 months with overall survival of 11.1 versus 7.0 months for low-dose versus high-dose group, indicating that high-dose regimens yielded worse response. The lower response seen with high doses may be explained by the downregulation of progesterone receptors. ${ }^{48}$ It is not clear why so many receptor-positive tumors do not respond to therapy and why some ER/PR-negative tumors do respond. Nevertheless, most studies do support low-grade histology, long disease-free interval, and expression of estrogen and/or progesterone receptors as important prognostic factors that predict a favorable response to progestin. ${ }^{47-50}$

\section{PROGESTERONE RECEPTORS IN ENDOMETRIAL CANCER}

Tumor progesterone receptor status has been studied in endometrial cancer specimens, with significant correlation between PR-positive tumors and grade, histology, adnexal spread, and recurrence. ${ }^{38,51}$ Ehrlich et al ${ }^{51}$ reported a clinical response rate to progesterone in 175 patients where $72 \%$ had PR-positive tumors and $12 \%$ had PR-negative tumors with improved overall survival in PR-positive tumors compared with the negative ones. Cancer recurrence has also been shown to occur more in PR-negative tumors. ${ }^{38,51}$ In recent years, the expression of PR-A and PR-B isoforms in endometrial adenocarcinoma using immunhistochemical staining has been made possible with specific antibodies to each of the isoforms. ${ }^{52}$ Using these antibodies, Leslie et al ${ }^{52}$ demonstrated that PR-A is localized to the nucleus, even in the absence of progesterone. In contrast, a large proportion of PR-B is cytoplasmic in the absence of ligand but is rapidly translocated to the nucleus in the presence of progesterone. They also demonstrated that all endometrial cancer specimens evaluated exhibited cytoplasmic PR-B in $250 \%$ of the cells, and five of the seven tumors that were moderately to poorly differentiated demonstrated no PR-B staining in the nuclei. Nuclear PR-B was thus significantly associated with increasing tumor differentiation. There is an ongoing debate as to the PR status in endometrial tumors, with one study suggesting that PR-B is predominant in advanced endometrial tumors, ${ }^{53}$ another study pointing to the loss of both isoforms in advanced endometrial cancer, ${ }^{54}$ and a third study that indicates only PR-A is expressed in poorly differentiated endometrial carcinoma cells. ${ }^{55}$ In a recent study, 
the evaluation of 315 tissue samples from endometrioid endometrial cancer revealed that PR-A and PR-B were associated lower grade tumors and that the ratio of PR-A to PR-B, if $<1$, was associated with a shorter disease-free survival and a shorter overall survival. ${ }^{56}$ Whether the ratio of PR-A and PR-B could be used as a prognostic tool to determine progesterone responsiveness is unknown.

\section{EFFECT OF PROGESTERONE ON ENDOMETRIAL HISTOLOGY}

In benign endometrium, it is well recognized that progestin treatment leads to stromal decidualization and inactive-appearing glands. However, there are few studies detailing the histopathological changes associated with progestin therapy for complex atypical hyperplasia and well-differentiated endometrioid carcinoma. Wheeler et al ${ }^{36}$ followed 44 patients with complex atypical hyperplasia or well-differentiated endometrioid carcinoma, treated with oral progestins or a levonorgestrel-releasing IUD. The responders to progestins exhibited histological changes including a decreased gland-to-stroma ratio, decreased glandular cellularity, decreased to absent mitotic activity, loss of cytologic atypia, and a variety of cytoplasmic changes including mucinous, secretory, squamous, and eosinophilic metaplasia. ${ }^{36}$ They also observed some architectural abnormalities, specifically cribriform and papillary patterns that were induced by progestins. Despite the lack of any biochemical analysis of proliferation or apoptosis in this study, it was apparent that progestins changed the histology and architecture of the diseased endometrium. Zheng et al ${ }^{57}$ reported that progestin therapy promoted involution or disappearance of phosphate and tensin homologue (PTEN) null endometrial glands. PTEN is the most common genetic alteration known in sporadic endometrioid endometrial carcinoma. ${ }^{58}$ Recently, it was demonstrated using atomic force microscopy that progesterone treatment induced changes to the cell surface of Hec-1A and Ishikawa cell lines, such as a flattened cell surface morphology with changes in cell height and surface convolution. This was a result of nanoscale molecular modifications in response to external hormonal treatments. ${ }^{59}$

\section{EFFECT OF PROGESTERONE ON ENDOMETRIAL CANCER CELL BEHAVIOR AND REGULATION OF GENES}

In vitro studies using endometrial cancer cell lines have provided insight into the effect of progesterone directly on cancer cell behavior and the genes that are regulated. In cell lines expressing either endogenous or recombinant PR, progesterone treatment can inhibit cell growth, invasion, and expression of cellular adhesion molecules, as well as promote differentiation to a secretory phenotype and induce replicative senescence. ${ }^{60-62}$ SmidKoopman et $\mathrm{al}^{62}$ demonstrated that in the presence of progesterone, PR-B expressing Ishikawa cells displayed almost complete inhibition of cell growth, and PR-A expressing Ishikawa cells only displayed 50\% inhibition of cell growth. In an additional study by Hanekamp et al, ${ }^{63}$ it was demonstrated that PR-B expressing Ishikawa cells caused more tumor growth in mice than PR-A expressing Ishikawa cells and that tumor growth was inhibited after administration of MPA only in cells expressing PR-B.

Numerous genes have been implicated in the progestin-mediated responses observed in endometrial cancer cells. Regulation of genes such as cyclin D1, MMP-1, -2, -7 and -9, and 
Ets-1 in response to progestins have been implicated to mediate the inhibition of cell growth and invasiveness. ${ }^{64}$ Primary cells from endometrial tumors also respond to progestins by significantly reducing pro-MMP-9, pro-MMP-2, and MMP-2 release. ${ }^{65}$ Progestins have been shown to induce glycodelin expression in Ishikawa cells, ${ }^{66-68}$ which causes inhibition of $\mathrm{G} 1 / \mathrm{S}$ progression and upregulation of CDKIs, thereby reducing cell proliferation. ${ }^{69}$ Overexpression of PR-A and PR-B in endometrial cancer cells resulted in a significant progesterone-dependent inhibition of expression of a cadre of cellular adhesion molecules, including fibronectin, integrin $\alpha 3$, integrin $\beta 1$, integrin $\beta 3$, and cadherin $6 .{ }^{60,70}$ Progestins can increase FOXO1 protein levels in Ishikawa cells, specifically through PR-B ${ }^{71}$ and promote cell cycle arrest and apoptosis in these cells. Interestingly, levels of FOXO1 protein are dramatically lower in $77 \%{ }^{72}$ or $95.9 \%{ }^{71}$ of endometrial tumor tissues studied compared with normal tissues from cycling endometrium. Shiozawa et $\mathrm{al}^{73}$ reported that $\mathrm{p} 27$ expression in hyperplastic epithelia was negligible before MPA treatment, whereas it was greatly increased after treatment. Watanabe et al demonstrated that it is through PR-B that p21 and p27 expression increases. ${ }^{74}$ Women with hyperplasia treated with either system MPA or a LNG-IUD exhibited increased apoptosis in the glandular cells with decreased expression of the antiapoptotic genes Bcl-2 and BAX. ${ }^{75}$

Microarray studies revealed that short-term (4 hour) and high-dose (30 ug/ml)) exposure of Ishikawa cells to progesterone resulted in 247 differentially expressed genes, of which 135 genes were involved in biological processes like cell cycle, cell proliferation and differentiation, developmental processes, immune responses, and intracellular protein traffic and transport. ${ }^{76}$ Other microarray studies where endometrial cancer cells were treated with progestins for a longer period of time identified inhibition of genes related to metastasis ${ }^{77}$ and regulation of genes associated with cell signaling, DNA remodeling, apoptosis, tumor suppressor, transcription factors, and anti-inflammatory cytokines. ${ }^{78}$

In endometrial cancer cells, it was shown that liganded PR decreases the transcriptional activity of the activating protein-1 (AP-1) transcription factor family and c-Jun in particular. In addition, progesterone strongly inhibited total AP-1 as well as c-Jun recruitment to the cyclin D1 promoter, whereas it enhanced AP-1 occupancy on the p53 and p21 promoters, as shown by chromatin immunoprecipitation assays. This study concluded that in endometrial cancer cells, modulation of AP-1 activity is a potential pathway of progesterone-induced growth inhibition in endometrial cancer cells. ${ }^{79}$ In the poorly differentiated endometrial cancer cells, Hec50c, expression of A20 and ABIN-2 were induced through PR-B and these factors that bind in a complex inhibited NFkappaB transcriptional activity. ${ }^{80}$ Thus it was proposed that the inhibition of NFkappaB by PR and its tumorigenic inflammatory and antiapoptotic effects was one pathway by which progesterone treatment is effective against endometrial hyperplasia and cancer. In another study, it was shown that progesterone upregulated COMT protein expression in Ishikawa cells primarily through PR-A. COMT converts genotoxic catecholestrogens to anticarcinogenic methoxyestrogens (2-ME2) in the endometrium. COMT promoter activity was differentially regulated by the three half-site progesterone response elements. Accordingly, high doses of 2-ME2 inhibited Ishikawa cell proliferation. ${ }^{81}$ 
Thus it is apparent that progesterone, through PR-A and PR-B, modulates genes that are involved in processes associated with cell cycle, apoptosis, cell adhesion, differentiation, and inflammation to regulate endometrial cancer cell behavior. The mechanism by which PR activates or represses these genes involves transcription factors and coregulators that are numerous and gene specific. There is still much to research in the area of progesteronedriven gene regulation in endometrial cancer, and we have only begun to scratch the surface.

\section{CONCLUSIONS AND PERSPECTIVES}

Endometrial adenocarcinoma is highly associated with unopposed estrogen action. The significance of progesterone in controlling estrogen-driven proliferation is underlined by its efficacy in preventing endometrial cancer. Progestins are used in the clinic effectively to eradicate some but not all endometrial hyperplasia and well-differentiated endometrioid endometrial cancer. It is also a mode of palliative therapy for recurrent endometrial cancer and does not eradicate the disease. The fact that progestin therapy is often associated with recurring disease is highly suggestive that progesterone response in the normal endometrium is very different from that of neoplastic or malignant tissues. Malignant cells are not the same as normal cells, and therefore mechanisms of progesterone action are expected to be different. Furthermore, the tissue composition of the normal endometrium is very different from the diseased endometrium. One example is the significant decrease in the amount of stroma observed in endometrial cancer compared with cycling endometrium. The stroma is highly responsive to progesterone and dynamically influences the epithelium in a paracrine manner. ${ }^{82-84}$ Without sufficient stroma, progesterone response would be compromised. Thus progesterone responsiveness may be dictated not only by the hyperplastic or malignant epithelium but also by the stroma. There is very little known of the role of stroma in response to progesterone in modulating glandular transformation and would be an area worth investigating to further understand how to prevent or to treat endometrial carcinoma.

Despite the lack of sufficient data sets to demonstrate the efficacy of progestin therapy in endometrial cancer, the case series and pilot studies do demonstrate that progestin therapy can be used effectively when surgery is not a desirable option. In addition, hormonal therapy is usually considered as first line of treatment for recurrent endometrial cancer because it is less toxic than chemotherapies. The questions remain as to why it is effective in only a subset of women and whether there are indicative markers to predict a positive outcome with progestin therapy. Is this characteristic of the loosely defined "progesterone resistence" observed in other uterine pathologies? What changes during malignant transformation contribute to progesterone resistance? How could the efficacy of progestin therapy be improved, especially in recurrent endometrial cancer? Can progestin therapy be combined with appropriate chemical compounds to eradicate endometrial tumors? How can progestins be used effectively to prevent endometrial cancer in the high-risk population?

Investigating the molecular mechanisms of progesterone action in endometrial cancer will be key in addressing some of the questions proposed. There is no doubt that progesterone action is complex and involves numerous pathways and players. The schematic shown in Fig. 2 summarizes progesterone action in endometrial cancer and is based on the studies previously mentioned. Progesterone, progestins, and progesterone modulators can act as 
ligands to PR. Depending on the isoforms present, similar and/or different group of genes are activated or repressed. Gene products will affect cell behavior, not only of the tumor but the neighboring cells as well. Cell/tissue architecture and composition can also change. The response to progesterone will ultimately manifest as death or regression of the tumor, cessation of growth, or no change in behavior. One can appreciate the potential that lies in progestin therapy given its vast modes of action. However, the process of elucidating such mechanisms can be at times fraught with significant limitations. The use of synthetic progestins both in clinic and in basic research complicate deciphering the true progesterone effect. These compounds vary in chemical structure, affinity, and specificity to PR. Much of the basic science research uses endometrial cancer cell lines that have been propagated over many years and have changed over time. Primary endometrial cancer cells are difficult to grow in vitro and thus limit any in-depth analysis of molecular pathways. There are numerous progesterone receptor antibodies that give conflicting data as to the relative levels of PR-A to PR-B and those that give prominent nonspecific signals. ${ }^{85}$ Curiously, the physiological effects of progesterone or progestins on cultured cells are relatively modest. Rarely do you see much influence of progestins on cell proliferation or apoptosis unless progesterone receptors are overexpressed or hormone concentrations are high (micromolar amounts) and treatment prolonged. The presence of serum also influences these responses. Despite these impediments, much knowledge in the effect of progesterone on endometrial cancer cells has been gained. Studies have shown that endometrial cancer cell behavior in response to progestins and the specific genes that are regulated are remarkably similar in cell lines grown in vitro, or as xenografts in vivo, and in endometrial tumors from women. Progesterone, through its receptor, can promote inhibition of growth and apoptosis of the tumors by regulating the genes that govern these processes.

Progestin therapy has been used for decades for many women as an alternative to surgery for endometrial neoplasias. A better understanding of its mode of action in the cases that do respond will be key in improving response rates to progestins. This can be accomplished by identifying the molecular mechanisms of progesterone action that differ between the responders and the resistors. It will also be important to study progesterone action not only on malignant cells but on neighboring cells, including stromal, endothelial, and immune cells that can influence the tumors. As risk factors and incidence of endometrial cancer rise, the use of progestins will become more prevalent for prevention and treatment of this disease. Use of innovative and state-of-the-art technology will be instrumental in moving this field forward.

\section{Acknowledgments}

We would like to acknowledge the Northwestern Memorial Foundation, Friends of Prentice, and CA127674 from the National Institutes of Health.

\section{REFERENCES}

1. Kurita, T.; Nakamura, H. Embryology and Anatomy of the Uterus. 2nd. Newark, NJ: Harwood Academic; 2007.

2. Clarke CL, Sutherland RL. Progestin regulation of cellular proliferation. Endocr Rev. 1990; 11(2): 266-301. [PubMed: 2114281] 
3. Dockery P, Li TC, Rogers AW, Cooke ID, Lenton EA. The ultrastructure of the glandular epithelium in the timed endometrial biopsy. Hum Reprod. 1988; 3(7):826-834. [PubMed: 3182973]

4. Wynn RM. Ultrastructural development of the human decidua. Am J Obstet Gynecol. 1974; 118(5): 652-670. [PubMed: 4813806]

5. Gellersen B, Brosens J. Cyclic AMP and progesterone receptor cross-talk in human endometrium: a decidualizing affair. J Endocrinol. 2003; 178(3):357-372. [PubMed: 12967329]

6. Mulac-Jericevic B, Mullinax RA, DeMayo FJ, Lydon JP, Conneely OM. Subgroup of reproductive functions of progesterone mediated by progesterone receptor-B isoform. Science. 2000; 289(5485): 1751-1754. [PubMed: 10976068]

7. Gronemeyer H, Meyer ME, Bocquel MT, Kastner P, Turcotte B, Chambon P. Progestin receptors: isoforms and antihormone action. J Steroid Biochem Mol Biol. 1991; 40(1-3):271-278. [PubMed: 1958531]

8. Kastner P, Krust A, Turcotte B, et al. Two distinct estrogen-regulated promoters generate transcripts encoding the two functionally different human progesterone receptor forms A and B. EMBO J. 1990; 9(5):1603-1614. [PubMed: 2328727]

9. Lessey BA, Alexander PS, Horwitz KB. The subunit structure of human breast cancer progesterone receptors: characterization by chromatography and photoaffinity labeling. Endocrinology. 1983; 112(4):1267-1274. [PubMed: 6682030]

10. Chi T, Lieberman P, Ellwood K, Carey M. A general mechanism for transcriptional synergy by eukaryotic activators. Nature. 1995; 377(6546):254-257. [PubMed: 7675113]

11. Giangrande PH, Kimbrel EA, Edwards DP, McDonnell DP. The opposing transcriptional activities of the two isoforms of the human progesterone receptor are due to differential cofactor binding. Mol Cell Biol. 2000; 20(9):3102-3115. [PubMed: 10757795]

12. McDonnell DP, Shahbaz MM, Vegeto E, Goldman ME. The human progesterone receptor A-form functions as a transcriptional modulator of mineralocorticoid receptor transcriptional activity. $\mathrm{J}$ Steroid Biochem Mol Biol. 1994; 48(5-6):425-432. [PubMed: 8180103]

13. Tetel MJ, Giangrande PH, Leonhardt SA, McDonnell DP, Edwards DP. Hormone-dependent interaction between the amino- and carboxyl-terminal domains of progesterone receptor in vitro and in vivo. Mol Endocrinol. 1999; 13(6):910-924. [PubMed: 10379890]

14. Tung L, Abdel-Hafiz H, Shen T, et al. Progesterone receptors (PR)-B and -A regulate transcription by different mechanisms: AF-3 exerts regulatory control over coactivator binding to PR-B. Mol Endocrinol. 2006; 20(11):2656-2670. [PubMed: 16762974]

15. Tung L, Mohamed MK, Hoeffler JP, Takimoto GS, Horwitz KB. Antagonist-occupied human progesterone B-receptors activate transcription without binding to progesterone response elements and are dominantly inhibited by A-receptors. Mol Endocrinol. 1993; 7(10):1256-1265. [PubMed: 8123133]

16. Vegeto E, Shahbaz MM, Wen DX, Goldman ME, O’Malley BW, McDonnell DP. Human progesterone receptor A form is a cell- and promoter-specific repressor of human progesterone receptor B function. Mol Endocrinol. 1993; 7(10):1244-1255. [PubMed: 8264658]

17. Wagner BL, Norris JD, Knotts TA, Weigel NL, McDonnell DP. The nuclear corepressors NCoR and SMRT are key regulators of both ligand- and 8-bromo-cyclic AMP-dependent transcriptional activity of the human progesterone receptor. Mol Cell Biol. 1998; 18(3):1369-1378. [PubMed: 9488452]

18. Mangal RK, Wiehle RD, Poindexter AN III, Weigel NL. Differential expression of uterine progesterone receptor forms A and B during the menstrual cycle. J Steroid Biochem Mol Biol. 1997; 63(4-6):195-202. [PubMed: 9459185]

19. Garcia E, Bouchard P, De Brux J, et al. Use of immunocytochemistry of progesterone and estrogen receptors for endometrial dating. J Clin Endocrinol Metab. 1988; 67(1):80-87. [PubMed: 2454244]

20. Mylonas I, Jeschke U, Shabani N, et al. Steroid receptors ERalpha, ERbeta, PR-A and PR-B are differentially expressed in normal and atrophic human endometrium. Histol Histopathol. 2007; 22(2):169-176. [PubMed: 17149689]

21. Snijders MP, de Goeij AF, Debets-Te Baerts MJ, Rousch MJ, Koudstaal J, Bosman FT. Immunocytochemical analysis of oestrogen receptors and progesterone receptors in the human 
uterus throughout the menstrual cycle and after the menopause. J Reprod Fertil. 1992; 94(2):363371. [PubMed: 1593539]

22. American Cancer Society. Cancer facts and figures. Atlanta, GA: American Cancer Society; 2008.

23. Creasman WT. Endometrial cancer: incidence, prognostic factors, diagnosis, and treatment. Semin Oncol. 1997; 24(1, Suppl 1):140-150.

24. Münstedt K, Grant P, Woenckhaus J, Roth G, Tinneberg HR. Cancer of the endometrium: current aspects of diagnostics and treatment. World J Surg Oncol. 2004; 2:24. [PubMed: 15268760]

25. Sherman ME. Theories of endometrial carcinogenesis: a multidisciplinary approach. Mod Pathol. 2000; 13(3):295-308. [PubMed: 10757340]

26. Gallup DG, Stock RJ. Adenocarcinoma of the endometriumin women 40 years of age or younger. Obstet Gynecol. 1984; 64(3):417-420. [PubMed: 6462572]

27. Trimble CL, Kauderer J, Zaino R, et al. Concurrent endometrial carcinoma in women with a biopsy diagnosis of atypical endometrial hyperplasia: a Gynecologic Oncology Group study. Cancer. 2006; 106(4):812-819. [PubMed: 16400639]

28. Reifenstein EC Jr. The treatment of advanced endometrial cancer with hydroxyprogesterone caproate. Gynecol Oncol. 1974; 2(2-3):377-414. [PubMed: 4616884]

29. Saegusa M, Okayasu I. Progesterone therapy for endometrial carcinoma reduces cell proliferation but does not alter apoptosis. Cancer. 1998; 83(1):111-121. [PubMed: 9655300]

30. Affinito P, Di Carlo C, Di Mauro P, Napolitano V, Nappi C. Endometrial hyperplasia: efficacy of a new treatment with a vaginal cream containing natural micronized progesterone. Maturitas. 1994; 20(2-3):191-198. [PubMed: 7715472]

31. Clark TJ, Neelakantan D, Gupta JK. The management of endometrial hyperplasia: an evaluation of current practice. Eur J Obstet Gynecol Reprod Biol. 2006; 125(2):259-264. [PubMed: 16246481]

32. Ferenczy A, Gelfand M. The biologic significance of cytologic atypia in progestogen-treated endometrial hyperplasia. Am J Obstet Gynecol. 1989; 160(1):126-131. [PubMed: 2912075]

33. Gal D, Edman CD, Vellios F, Forney JP. Long-term effect of megestrol acetate in the treatment of endometrial hyperplasia. Am J Obstet Gynecol. 1983; 146(3):316-322. [PubMed: 6859142]

34. Varma R, Soneja H, Bhatia K, et al. The effectiveness of a levonorgestrel-releasing intrauterine system (LNG-IUS) in the treatment of endometrial hyperplasia-a long-term follow-up study. Eur J Obstet Gynecol Reprod Biol. 2008; 139(2):169-175. [PubMed: 18440693]

35. Randall TC, Kurman RJ. Progestin treatment of atypical hyperplasia and well-differentiated carcinoma of the endometrium in women under age 40. Obstet Gynecol. 1997; 90(3):434-440. [PubMed: 9277658]

36. Wheeler DT, Bristow RE, Kurman RJ. Histologic alterations in endometrial hyperplasia and welldifferentiated carcinoma treated with progestins. Am J Surg Pathol. 2007; 31(7):988-998. [PubMed: 17592264]

37. Ushijima K, Yahata H, Yoshikawa H, et al. Multicenter phase II study of fertility-sparing treatment with medroxyprogesterone acetate for endometrial carcinoma and atypical hyperplasia in young women. J Clin Oncol. 2007; 25(19):2798-2803. [PubMed: 17602085]

38. Ramirez PT, Frumovitz M, Bodurka DC, Sun CC, Levenback C. Hormonal therapy for the management of grade 1 endometrial adenocarcinoma: a literature review. Gynecol Oncol. 2004; 95(1):133-138. [PubMed: 15385122]

39. Chiva L, Lapuente F, González-Cortijo L, et al. Sparing fertility in young patients with endometrial cancer. Gynecol Oncol. 2008; 111(2, Suppl):S101-S104. [PubMed: 18804267]

40. Kim YB, Holschneider CH, Ghosh K, Nieberg RK, Montz FJ. Progestin alone as primary treatment of endometrial carcinoma in premenopausal women. Report of seven cases and review of the literature. Cancer. 1997; 79(2):320-327. [PubMed: 9010105]

41. Montz FJ, Bristow RE, Bovicelli A, Tomacruz R, Kurman RJ. Intrauterine progesterone treatment of early endometrial cancer. Am J Obstet Gynecol. 2002; 186(4):651-657. [PubMed: 11967486]

42. Dhar KK, NeedhiRajan T, Koslowski M, Woolas RP. Is levonorgestrel intrauterine system effective for treatment of early endometrial cancer? Report of four cases and review of the literature Gynecol Oncol. 2005; 97(3):924-927. [PubMed: 15943993] 
43. Jones K, Georgiou M, Hyatt D, Spencer T, Thomas H. Endometrial adenocarcinoma following the insertion of a Mirena IUCD. Gynecol Oncol. 2002; 87(2):216-218. [PubMed: 12477456]

44. Kresowik J, Ryan GL, Van Voorhis BJ. Progression of atypical endometrial hyperplasia to adenocarcinoma despite intrauterine progesterone treatment with the levonorgestrel-releasing intrauterine system. Obstet Gynecol. 2008; 111(2 Pt 2):547-549. [PubMed: 18239018]

45. Kelley RM, Baker WH. Progestational agents in the treatment of carcinoma of the endometrium. N Engl J Med. 1961; 264:216-222. [PubMed: 13752346]

46. Piver MS, Barlow JJ, Lurain JR, Blumenson LE. Medroxyprogesterone acetate (Depo-Provera) vs. hydroxyprogesterone caproate (Delalutin) in women with metastatic endometrial adenocarcinoma. Cancer. 1980; 45(2):268-272. [PubMed: 6985833]

47. Decruze SB, Green JA. Hormone therapy in advanced and recurrent endometrial cancer: a systematic review. Int J Gynecol Cancer. 2007; 17(5):964-978. [PubMed: 17442022]

48. Thigpen JT, Brady MF, Alvarez RD, et al. Oral medroxyprogesterone acetate in the treatment of advanced or recurrent endometrial carcinoma: a dose-response study by the Gynecologic Oncology Group. J Clin Oncol. 1999; 17(6):1736-1744. [PubMed: 10561210]

49. Markman M. Hormonal therapy of endometrial cancer. Eur J Cancer. 2005; 41(5):673-675. [PubMed: 15763641]

50. Quinn MA, Cauchi M, Fortune D. Endometrial carcinoma: steroid receptors and response to medroxyprogesterone acetate. Gynecol Oncol. 1985; 21(3):314-319. [PubMed: 3159630]

51. Ehrlich CE, Young PC, Stehman FB, Sutton GP, Alford WM. Steroid receptors and clinical outcome in patients with adenocarcinoma of the endometrium. Am J Obstet Gynecol. 1988; 158(4):796-807. [PubMed: 2966586]

52. Leslie KK, Stein MP, Kumar NS, et al. Progesterone receptor isoform identification and subcellular localization in endometrial cancer. Gynecol Oncol. 2005; 96(1):32-41. [PubMed: 15589577]

53. Fujimoto J, Ichigo S, Hori M, Nishigaki M, Tamaya T. Expression of progesterone receptor form A and B mRNAs in gynecologic malignant tumors. Tumour Biol. 1995; 16(4):254-260. [PubMed: 7604206]

54. Arnett-Mansfield RL, deFazio A, Wain GV, et al. Relative expression of progesterone receptors A and B in endometrioid cancers of the endometrium. Cancer Res. 2001; 61(11):4576-4582. [PubMed: 11389093]

55. Kumar NS, Richer J, Owen G, Litman E, Horwitz KB, Leslie KK. Selective down-regulation of progesterone re+Although+ceptor isoform B in poorly differentiated human endometrial cancer cells: implications for unopposed estrogen action. Cancer Res. 1998; 58(9):1860-1865. [PubMed: 9581825]

56. Jongen V, Briët J, de Jong R, et al. Expression of estrogen receptor-alpha and -beta and progesterone receptor-A and $-\mathrm{B}$ in a large cohort of patients with endometrioid endometrial cancer. Gynecol Oncol. 2009; 112(3):537-542. [PubMed: 19108875]

57. Zheng W, Baker HE, Mutter GL. Involution of PTEN-null endometrial glands with progestin therapy. Gynecol Oncol. 2004; 92(3):1008-1013. [PubMed: 14984979]

58. Mutter GL, Lin MC, Fitzgerald JT, et al. Altered PTEN expression as a diagnostic marker for the earliest endometrial precancers. J Natl Cancer Inst. 2000; 92(11):924-930. [PubMed: 10841828]

59. Francis LW, Lewis PD, Gonzalez D, et al. Progesterone induces nano-scale molecular modifications on endometrial epithelial cell surfaces. Biol Cell. 2009; 101(8):481-491. [PubMed: 19236310]

60. Dai D, Wolf DM, Litman ES, White MJ, Leslie KK. Progesterone inhibits human endometrial cancer cell growth and invasiveness: down-regulation of cellular adhesion molecules through progesterone B receptors. Cancer Res. 2002; 62(3):881-886. [PubMed: 11830547]

61. Ueda M, Fujii H, Yoshizawa K, Abe F, Ueki M. Effects of sex steroids and growth factors on migration and invasion of endometrial adenocarcinoma SNG-M cells in vitro. Jpn J Cancer Res. 1996; 87(5):524-533. [PubMed: 8641991]

62. Smid-Koopman E, Blok LJ, Kühne LC, et al. Distinct functional differences of human progesterone receptors $\mathrm{A}$ and $\mathrm{B}$ on gene expression and growth regulation in two endometrial carcinoma cell lines. J Soc Gynecol Investig. 2003; 10(1):49-57. 
63. Hanekamp EE, Kühne LM, Grootegoed JA, Burger CW, Blok LJ. Progesterone receptor A and B expression and progestagen treatment in growth and spread of endometrial cancer cells in nude mice. Endocr Relat Cancer. 2004; 11(4):831-841. [PubMed: 15613456]

64. Saito T, Mizumoto H, Tanaka R, et al. Overexpressed progesterone receptor form B inhibit invasive activity suppressing matrix metalloproteinases in endometrial carcinoma cells. Cancer Lett. 2004; 209(2):237-243. [PubMed: 15159027]

65. Di Nezza LA, Jobling T, Salamonsen LA. Progestin suppresses matrix metalloproteinase production in endometrial cancer. Gynecol Oncol. 2003; 89(2):325-333. [PubMed: 12713999]

66. Jaffe RC, Ferguson-Gottschall SD, Gao W, Beam C, Fazleabas AT. Histone deacetylase inhibition and progesterone act synergistically to stimulate baboon glycodelin gene expression. J Mol Endocrinol. 2007; 38(3):401-407. [PubMed: 17339403]

67. Uchida H, Maruyama T, Nagashima T, Asada H, Yoshimura Y. Histone deacetylase inhibitors induce differentiation of human endometrial adenocarcinoma cells through up-regulation of glycodelin. Endocrinology. 2005; 146(12):5365-5373. [PubMed: 16123169]

68. Uchida H, Maruyama T, Ono M, et al. Histone deacetylase inhibitors stimulate cell migration in human endometrial adenocarcinoma cells through up-regulation of glycodelin. Endocrinology. 2007; 148(2):896-902. [PubMed: 17068141]

69. Ohta K, Maruyama T, Uchida H, et al. Glycodelin blocks progression to S phase and inhibits cell growth: a possible progesterone-induced regulator for endometrial epithelial cell growth. Mol Hum Reprod. 2008; 14(1):17-22. [PubMed: 18178606]

70. Dai D, Kumar NS, Wolf DM, Leslie KK. Molecular tools to reestablish progestin control of endometrial cancer cell proliferation. Am J Obstet Gynecol. 2001; 184(5):790-797. [PubMed: 11303185]

71. Ward EC, Hoekstra AV, Blok LJ, et al. The regulation and function of the forkhead transcription factor, Forkhead box O1, is dependent on the progesterone receptor in endometrial carcinoma. Endocrinology. 2008; 149(4):1942-1950. [PubMed: 18096667]

72. Goto T, Takano M, Albergaria A, et al. Mechanism and functional consequences of loss of FOXO1 expression in endometrioid endometrial cancer cells. Oncogene. 2008; 27(1):9-19. [PubMed: 17599040]

73. Shiozawa T, Nikaido T, Nakayama K, Lu X, Fujii S. Involvement of cyclin-dependent kinase inhibitor p27Kip1 in growth inhibition of endometrium in the secretory phase and of hyperplastic endometrium treated with progesterone. Mol Hum Reprod. 1998; 4(9):899-905. [PubMed: 9783852]

74. Watanabe J, Watanabe K, Jobo T, et al. Significance of p27 as a predicting marker for medroxyprogesterone acetate therapy against endometrial endometrioid adenocarcinoma. Int J Gynecol Cancer. 2006; 16(Suppl 1):452-457. [PubMed: 16515645]

75. Vereide AB, Kaino T, Sager G, Ørbo A. Scottish Gynaecological Clinical Trials Group. Bcl-2, BAX, and apoptosis in endometrial hyperplasia after high dose gestagen therapy: a comparison of responses in patients treated with intrauterine levonorgestrel and systemic medroxyprogesterone. Gynecol Oncol. 2005; 97(3):740-750. [PubMed: 15885761]

76. Paulssen RH, Moe B, Grønaas H, Orbo A. Gene expression in endometrial cancer cells (Ishikawa) after short time high dose exposure to progesterone. Steroids. 2008; 73(1):116-128. [PubMed: 18037150]

77. Hanekamp EE, Kühne EC, Smid-Koopman E, et al. Loss of progesterone receptor may lead to an invasive phenotype in human endometrial cancer. Eur J Cancer. 2002; 38(Suppl 6):S71-S72. [PubMed: 12409083]

78. Davies S, Dai D, Wolf DM, Leslie KK. Immunomodulatory and transcriptional effects of progesterone through progesterone A and B receptors in Hec50co poorly differentiated endometrial cancer cells. J Soc Gynecol Investig. 2004; 11(7):494-499.

79. Dai D, Litman ES, Schonteich E, Leslie KK. Progesterone regulation of activating protein-1 transcriptional activity: a possible mechanism of progesterone inhibition of endometrial cancer cell growth. J Steroid Biochem Mol Biol. 2003; 87(2-3):123-131. [PubMed: 14672732]

80. Davies S, Dai D, Feldman I, Pickett G, Leslie KK. Identification of a novel mechanism of NFkappaB inactivation by progesterone through progesterone receptors in Hec50co poorly 
differentiated endometrial cancer cells: induction of A20 and ABIN-2. Gynecol Oncol. 2004; 94(2):463-470. [PubMed: 15297189]

81. Salih SM, Salama SA, Jamaluddin M, et al. Progesterone-mediated regulation of catechol-Omethyl transferase expression in endometrial cancer cells. Reprod Sci. 2008; 15(2):210-220. [PubMed: 18089588]

82. Tamura M, Sebastian S, Yang S, et al. Up-regulation of cyclooxygenase-2 expression and prostaglandin synthesis in endometrial stromal cells by malignant endometrial epithelial cells. A paracrine effect mediated by prostaglandin E2 and nuclear factor-kappa B. J Biol Chem. 2002; 277(29):26208-26216. [PubMed: 12006564]

83. Yang S, Fang Z, Gurates B, et al. Stromal PRs mediate induction of 17beta-hydroxysteroid dehydrogenase type 2 expression in human endometrial epithelium: a paracrine mechanism for inactivation of E2. Mol Endocrinol. 2001; 15(12):2093-2105. [PubMed: 11731611]

84. Lee K, Jeong J, Tsai MJ, et al. Molecular mechanisms involved in progesterone receptor regulation of uterine function. J Steroid Biochem Mol Biol. 2006; 102(1):41-50. [PubMed: 17067792]

85. Samalecos A, Gellersen B. Systematic expression analysis and antibody screening do not support the existence of naturally occurring progesterone receptor (PR)-C, PR-M, or other truncated PR isoforms. Endocrinology. 2008; 149(11):5872-5887. [PubMed: 18617611] 

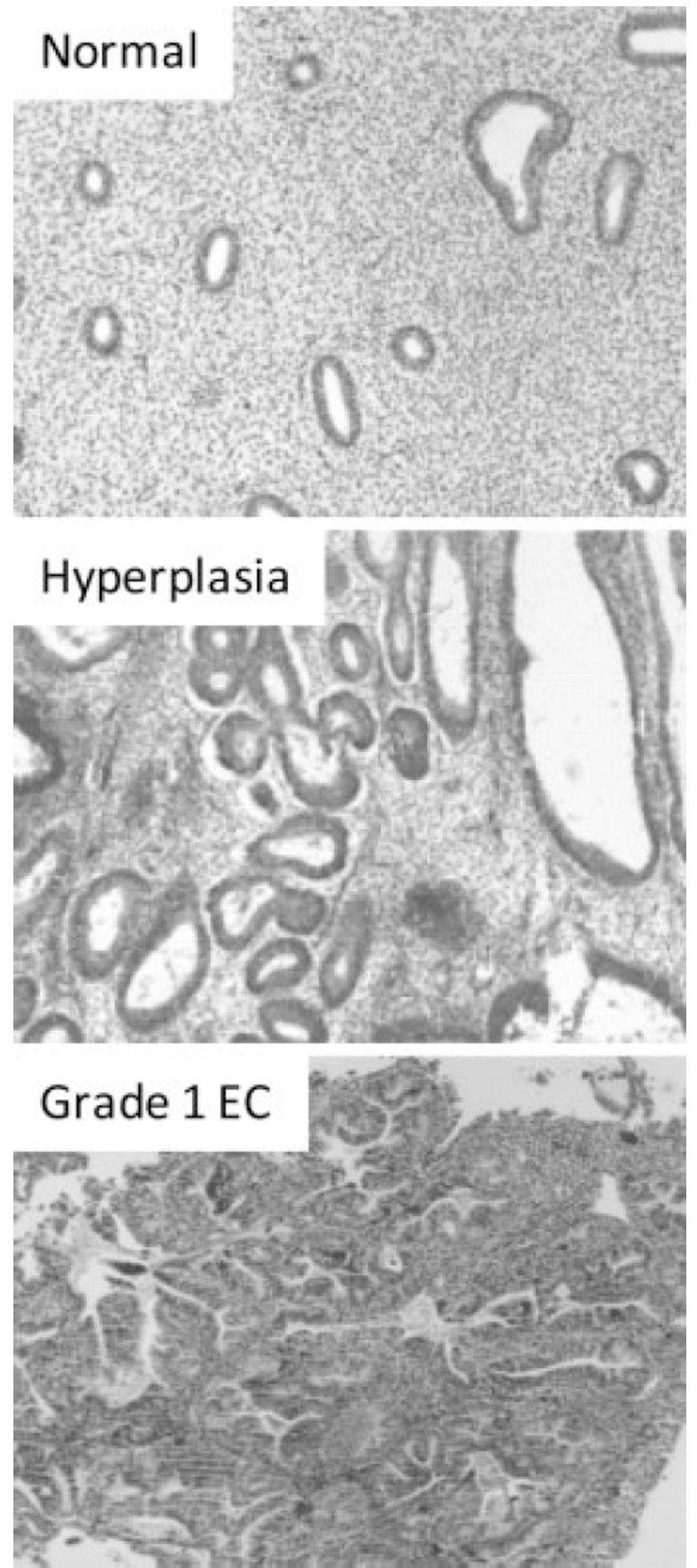

Figure 1.

Endometrial tissues were stained with hematoxylin and eosin to distinguish morphology. Depicted are sections of normal, hyperplasia, and endometrial cancer tissues. Notice the change in glandular morphology in hyperplasia and grade 1 endometrial carcinoma. 


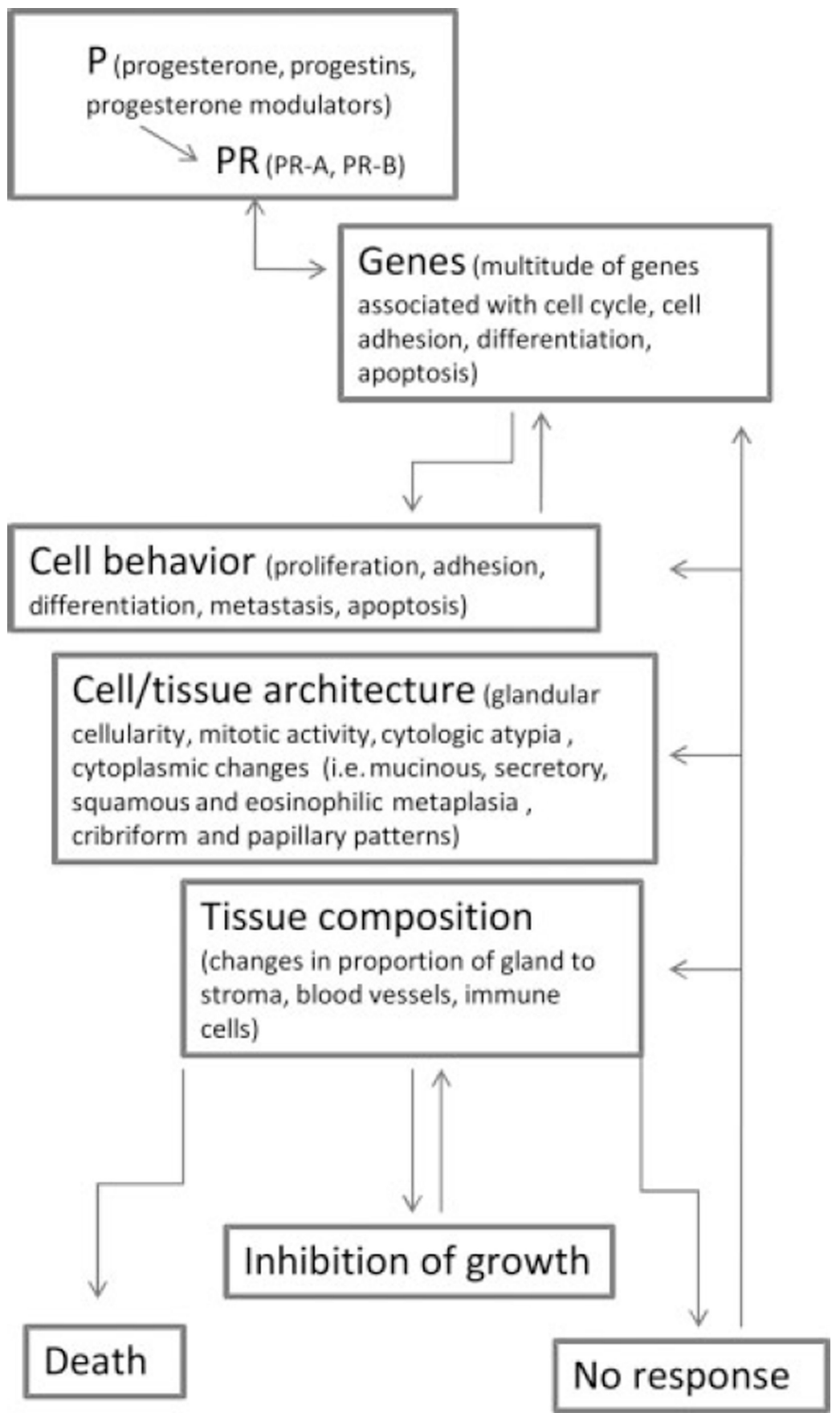

Figure 2.

Schematic illustration of progesterone action on endometrial carcinoma. The complexity of progesterone action can be appreciated because all processes interconnect and influence the tumor response. 